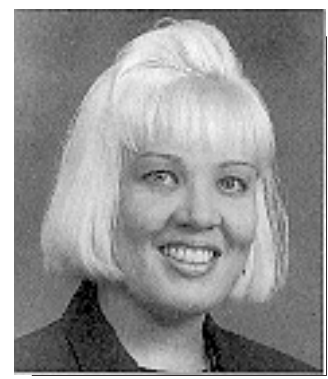

\title{
DINE PM -projekti tuo tasa-arvoa koulumaailmaan
}

\author{
Entisen Mikkelin läänin koulut on verkotettu kuva- ja ääniyhtey- \\ teen tietokoneisiin asennettujen videoneuvottelulaitteiden avulla. \\ Projektin 19 miljoonan markan kustannuksista kolmasosa on \\ saatu EU-rahoituksena. Lopusta vastaavat opetusministeriö, \\ projektiin osallistujat ja muutama alueen yritys. \\ Tavoitteena on tarjota harvaanasutun alueen ihmisille suurten \\ taajamien oppimismahdollisuudet. Etäopiskelun ansiosta opetta- \\ jat ja yritysten työntekijät on saatu pienin \\ kustannuksin koulutuksen piiriin.
}

\begin{abstract}
DINE PM (Distance Independent Education in Province of Mikkeli) eli Etäisyyksistä riippumaton opetus Mikkelin läänissä -projekti käynnistyi syyskuussa 1996. Suunnitteluvaiheessa edellisenä talvena eri oppilaitoksilta tiedusteltiin halukkuutta osallistua etäkoulutushankkeeseen, joka edellytti aktiivista sitoutumista toiminnan kehittämiseen. Eriasteisia oppilaitoksia ilmoittautui mukaan kiitettävä määrä kaikilta eri kouluasteilta koko läänin alueelta.
\end{abstract}

Vuoteen 2000 kestävän projektin tavoitteena on kouluttaa opettajia videoneuvottelulaitteiden käyttäjiksi opetustyössään. Verkottumisella ja etäopetuksen soveltamisella laaja valinnaisuus oppiaineissa saavutetaan myös silloin, kun oppilaitos ei voi järjestää esimerkiksi vieraiden kielten opetusta vähien varojen ja oppilasryhmien pienuuden vuoksi. Lisäksi pyritään nostamaan alueen elinkeinoelämässä olevien henkilöiden tietoteknistä tasoa ja kannustetaan heitä kehittämään telemaattisia yhteyksiä yritystoiminnan parantamiseksi.

\section{Laitteistojen hankinta}

Laitteistojen hankinta oli tärkeä osa telemaattisen opetusverkon rakentamista. Lisäksi tarvittiin puhelinyhtiöiden tuottamat yhteydet oppilaitoksille. Hinta ja toiminnalliset ominaisuudet asettivat tietyn rajan laitteiden kokonaismäärälle. EU:n direktiivien mukaisten tarjouspyyntöjen perusteella päädyttiin nykyiseen laitteistoon. Se sisältää tietokoneen, videoneuvotteluohjelman ja sen edellyttämät lisälaitteet.

Tietokoneet ovat Pentium-tasoisia ja niissä on Windows95-käyttöjärjestelmä, Microsoft Office- toimistopaketti, äärikortti, kaiuttimet sekä cd-rom-asema. Videoneuvottelulaitteistoon kuuluvat Picture'Tel Live50 -kortit sekä ohjelmistot, videokamera, korvamikrofoni tai kaiu- 


\section{UUTTAKOULUTUKSESSA}

tinpuhelin ja kameranjalusta. Oppilaitosten tehtäväksi jäi hankkia puhelinliittymä, jonka puhelinyhtiöt muuttivat nopeaksi ISDN-yhteydeksi. Laitteiston keskihinnaksi tuli noin 35000 markkaa, josta oppilaitosten osuus oli 20 prosenttia. Videoneuvottelulaitteita sijoitettiin aina päiväkodista yliopistollisiin oppilaitoksiin asti. Laitteistot jaettiin oppilaitoksille saatetilaisuuksissa, joissa esiteltiin laitteet ja annettiin peruskoulutus niiden toimintaperiaatteista.

Yhteensä laitteistoja on nyt toiminnassa 180 . Noin 60 prosenttia laitteistoista on sijoitettu alaasteille. Lukioissa ja yläasteilla on 15 prosenttia, kansan- ja kansalaisopistoissa 10 prosenttia ja ammattioppilaitoksissa 12 prosenttia laitteista. Fyysiset sijoituspaikat vaihtelevat auditorioista atk-luokkiin, studioista varastoihin.

\section{Kouluttajien ja opettajien koulutus}

Projektin alkuvaiheessa koulutettiin 15 kouluttajaa. Koulutuksen sisältö oli varsin monisäikeinen. Ensin ohjelmassa olivat laitteisiin tutustuminen sekä projektin tavoitteiden läpikäyminen. Tietotekniikkakoulutusta seurasi aikuiskasvatuksen opiskelu Jyväskylän Yliopiston Täydennyskoulutuskeskuksen alaisuudessa.

Kouluttajakoulutuksessa korostettiin, että videoneuvottelu osana oppimista vaatii uudenlaista ajattelutapaa niin kouluttajalta kuin koulutettavaltakin. Video-opetuksen suunnittelu ja esiintyminen kameran edessä usein vieraalle kuulijakunnalle on opettajille uusi kokemus. Se vaatii työskentelytapojen ja ennen kaikkea asenteiden muutosta. Opettaja ei voi luennoida vaan hänen pitää luoda tuntiin vuorovaikutusta kysymysten, keskustelujen ja erilaisten tehtävien kautta.

Kouluttajien perehdyttämisen jälkeen alkoi itse laitteiden loppukäyttäjien eli opettajien koulutus. Kouluttajat ovat antaneet videoneuvottelulaitteiston käyttökoulutusta ja tietotekniikkakoulutusta lokakuusta 1996 lähtien 549 opettajalle ja muulle koulun henkilöstölle yhteensä 1001 tuntia. Tarkoituksena on ollut kouluttaa vähintään kaksi käyttäjää laitteistoa kohti. Op- pimateriaalin kouluttajat ovat joutuneet laatimaan itse, sillä vastaavia kursseja ei ole aikaisemmin järjestetty. Kokemukset uudesta oppimisympäristöstä ovat olleet positiivisia. Etäisyydet ovat kadonneet ja koulutus laitteiden välityksellä on onnistunut. Myös ulkoiset puitteet alkavat hahmottua ja olla kunnossa. Yhteydet ovat toimineet ja aikataulut pitäneet.

Kouluttajat ovat antaneet opettajille yksilö-, silta- ja lähikoulutusta. Yksilöllinen opetus ei välttämättä ole täysin kahdenkeskistä vaan videokameran ääressä eri pisteissä voi tilanteen mukaan olla kouluttajan lisäksi kaksi tai kolme opiskelijaa. Ohjaus on todettu tehokkaaksi ja vuorovaikutus yhtä tiiviiksi kuin jos keskustelijat istuisivat saman pöydän ääressä. Myös etätyökalut ovat tarjonneet hyvät mahdollisuudet havainnoillistamisessa ja tiedonkulussa. Videoneuvottelun aikana sen osapuolet voivat esimerkiksi työstää molempien näytöillä näkyvää Microsoft Word-ohjelmaa ja siirtää toisilleen tiedostoja.

Monipisteyhteyksien on havaittu soveltuvan keskustelufoorumiksi ja luentotyyppiseen koulutukseen. Siinä kouluttaja antaa opetusta samanaikaisesti useaan pisteeseen. Kaikki näkevät kuvan sieltä, mistä sillä hetkellä puhutaan.

\section{Käytännön työ ja kokemukset}

Koulutusvaiheen jälkeen opettajat ovat pikkuhiljaa alkaneet käyttää videoneuvottelulaitteita työssään. Tähän mennessä niitä on käytetty eniten kielten oppimisessa. Etäopetuksena on opittu muun muassa saksaa, ranskaa, venäjää, kreikkaa ja unkaria. Esimerkiksi Heinäveden kansalaisopiston opettaja on tullut videoneuvottelun kautta pitämään unkarin kielen jatkokurssia kyliin. Mäntyharjun kansalaisopiston opiskelijat ovat ottaneet säännöllisiä videoyhteyksiä Tampereen yliopistoon kunnallishallinnon approbaturin suorittamiseksi. Kaikenikäiset oppilaat ovat ylipäätään pitäneet opetusmuodosta ja oppimistulokset ovat olleet lupaavia. Opettajat ovat olleet innostuneita uuteen opetusmuotoon, joskin materiaalin valmistami- 
nen on alkuvaiheessa tuottanut paljon lisätyötä. Koska opettaminen videoneuvottelulaitteiden välityksellä ei ole samanlaista kuin luokassa opettaminen, opetusmateriaali on täytynyt laittaa uuteen uskoon. Sen vuoksi opettajien yleisenä toivomuksena on ollut, että kustantamot ottaisivat jatkossa huomioon telemaattisen opetusmateriaalin teon. Opetus tällä saralla tullee joka tapauksessa tulevaisuudessa lisääntymään.

Oppilaitokset aikovat lisätä keskinäistä yhteistyötä kaikkien aineiden opetuksessa. Suunnitteilla on paljon pieniä projektiluontoisia opetustilanteita, lyhytkursseja sekä ryhmätöitä eri koulujen oppilaiden kesken. Oppilaat ovat olleet innoissaan päästessään suoraan yhteyteen esimerkiksi eduskunnan kanssa ja voidessaan kokeilla kielitaitoaan ulkomaisissa yhteyksissä. Uusi videoneuvottelun aluevaltaus DINE PM - projektissa on koulutus, jossa laitteet viedään työpaikoille. Koulutus on tarkoitettu pk-yrityksille, jotka haluavat antaa työntekijöilleen tietotekniikan opetusta.

Lokakuussa aloitettiinyhteistyössä Oulun yliopiston ja Otavan opiston kanssa 15:n opintoviikon laajuinen koulutusteknologia-kurssi. Sen tavoitteena on hankkia valmiuksia uusien koulutustapojen suunnitteluun ja uuden teknologian soveltamiseen. Lisäksi suunnitteilla on järjestää yhteistyössä Otavan sosiaalialan oppilaitoksen kanssa etäkoulutusta 0-luokkien koulunkäyntiavustajille.

\section{USÄTIETOJA:}

opetustoimentarkastaja, projektipäällikkö Erkki Mustajo ki, puh. 015-1912 330, email:erkki.mustajoki@mikkeliamk.fi 